\title{
HÁ TODO UM BRANCO POR PERCORRER
}

\author{
Mariana Borges Nobre Lopes \\ marynobry@hotmail.com
}

Era inverno e talvez isso fosse menos importante. Importante era o vento que poderia também ser de outono. Um vento capaz de entrar pelo meu apartamento de janelas densas e sempre fechadas, sacodindo as cortinas e, fatalmente, quebrando o jogo de chá recém-lavado que nunca esteve sobre a pia. Feitos muitos cacos daquela louça branca que uma amiga nunca trouxe de alguma viagem, restaria eu, impelido pelo vento a flutuar em rodopios loucos pelos cômodos.

Na cozinha, você procuraria por outra louça, um vidro inteiro e quente nos faria um chá. Eu afoitamente abandonaria a xícara no branco de cacos e seguiria por eles no escuro da tarde que rapidamente quer fazer-se noite, à procura das suas mãos.

“Convergências que o pudor público rejeitou”

Em goladas ligeiras e entrecortadas, você pediria que acabássemos o chá. Sem medo de cortes, eu seguiria na busca. Afinal, o vento já haveria cretinamente estraçalhado os limites e devassado o recôndito. "Quente o vapor que emana dos inteiros”. Daí seguiria toda uma saudade, todo um remorso. Um medo. Medo mesmo de pisar onde nunca estivemos. 